\title{
Expansion of the $\alpha_{2}$-adrenergic receptor family: Cloning and characterization of a human $\alpha_{2}$-adrenergic receptor subtype, the gene for which is located on chromosome 2
}

(catecholamines/G protein/ $\boldsymbol{\alpha}_{2}$-adrenoceptor $/\left[{ }^{3} \mathrm{H}\right]$ yohimbine binding/polymerase chain reaction)

\author{
Jon W. Lomasney*, Wulfing Lorenz ${ }^{\dagger}$, Lee F. Allen ${ }^{\dagger}$, Klim King $^{\dagger \ddagger}$, John W. Regan $\$$,

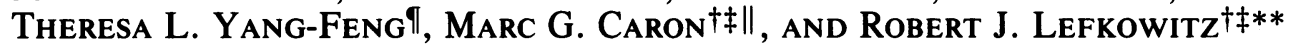

Departments of *Pathology, ${ }^{\dagger}$ Medicine, "Cell Biology, and **Biochemistry, and the ${ }^{\ddagger}$ Howard Hughes Medical Institute, Duke University Medical Center, Durham, NC 27710; § Department of Pharmacology, University of Arizona, Tucson, AZ 85721; and 'Department of Human Genetics, Yale University School of Medicine, New Haven, CT 06510

Contributed by Robert J. Lefkowitz, April 23, 1990

\begin{abstract}
Pharmacologic, biochemical, and genetic analyses have demonstrated the existence of multiple $\alpha_{2}$ adrenergic receptor $\left(\alpha_{2} A R\right)$ subtypes. We have cloned a human $\alpha_{2} A R$ by using the polymerase chain reaction with oligonucleotide primers homologous to conserved regions of the previously cloned $\alpha_{2} A R s$, the genes for which are located on human chromosomes $4(\mathrm{C} 4)$ and $10(\mathrm{C10})$. The deduced amino acid sequence encodes a protein of $\mathbf{4 5 0}$ amino acids whose putative topology is similar to that of the family of guanine nucleotidebinding protein-coupled receptors, but whose structure most closely resembles that of the $\alpha_{2} A R s$. Competition curve analysis of the binding properties of the receptor expressed in COS-7 cells with a variety of adrenergic ligands demonstrates a unique $\alpha_{2} \mathrm{AR}$ pharmacology. Hybridization with somatic cell hybrids shows that the gene for this receptor is located on chromosome 2. Northern blot analysis of various rat tissues shows expression in liver and kidney. The unique pharmacology and tissue localization of this receptor suggest that this is an $\alpha_{2} A R$ subtype not previously identified by classical pharmacological or ligand binding approaches.
\end{abstract}

The catecholamines, epinephrine and norepinephrine, mediate various physiological effects in different tissues by binding to different subtypes of adrenergic receptors $\left(\beta_{1}, \beta_{2}, \alpha_{1}\right.$, $\alpha_{2}$ ). The adrenergic receptors are currently classified according to their unique pharmacology. This classification has been both confirmed and expanded by the cloning of the genes for these receptors (1-7). While the genes encoding these receptors are distinct, they are quite homologous and are members of the growing family of guanine nucleotide-binding regulatory protein ( $G$ protein)-coupled receptors $(8)$. This family also contains the muscarinic cholinergic, substance $K$, lutropin-choriogonadotropin, thyrotropin, serotonin, and dopaminergic receptors, as well as rhodopsin.

Heterogeneity of $\alpha_{2}$-adrenergic receptors ( $\left.\alpha_{2} \mathrm{ARs}\right)$ has been demonstrated in several pharmacological studies by showing different rank orders of potency for several compounds at $\alpha_{2} \mathrm{AR}$ binding sites (9-12). Accordingly, three subtypes have been proposed $\left(\alpha_{2 \mathrm{~A}}, \alpha_{2 \mathrm{~B}}, \alpha_{2 \mathrm{C}}\right)$ based on the differential potencies of prazosin, oxymetazoline, yohimbine, ARC 239, and chlorpromazine. Other evidence for multiple $\alpha_{2} \mathrm{AR}$ subtypes includes the demonstration of pre- and postsynaptic receptor localizations $(13,14)$. In addition, our laboratory has shown that a probe made from the human platelet $\alpha_{2} \mathrm{AR}$ gene recognizes, at moderately high stringency, three different genes by Southern blot analysis of DNA from somatic cell hybrids (1). Each of these genes localizes to a different human

The publication costs of this article were defrayed in part by page charge payment. This article must therefore be hereby marked "advertisement" in accordance with 18 U.S.C. $\$ 1734$ solely to indicate this fact. chromosome: 2,4 , or $10\left(\alpha_{2} \mathrm{C} 2, \alpha_{2} \mathrm{C} 4\right.$, and $\left.\alpha_{2} \mathrm{C} 10\right)$. The human platelet $\alpha_{2} \mathrm{AR}$ gene is located on chromosome 10. The gene for a second $\alpha_{2} \mathrm{AR}$, which has been cloned from a human kidney cDNA library, is located on chromosome 4 . We now report the cloning of a human $\alpha_{2} \mathrm{AR}$ whose gene is located on chromosome $2 . \dagger^{\dagger}$ The pharmacological properties of this receptor as well as its tissue distribution by Northern blot analysis suggest that the heterogeneity of this set of receptors may extend beyond the three pharmacologically defined subtypes.

\section{MATERIALS AND METHODS}

Polymerase Chain Reaction (PCR) Cloning. Oligonucleotide primers (primer A, 5'-GTGCAAGCTTGCACCTCGTCGATCGTGCATCTGTGNGC-3'; primer B, 5'-CCCAAAGAGCTCAGCCAGCACAAAGGTGAAGCG-3') corresponding to identified $\alpha_{2} \mathrm{AR}$ consensus sequences were synthesized on an Applied Biosystems 380 B DNA synthesizer and purified on a $16 \%$ (wt/vol) denaturing polyacrylamide gel or by HPLC using an Applied Biosystems Aquapore RP-300 column and a 5-95\% acetonitrile gradient (15). The primers were designed with the restriction endonuclease linkers HindIII and Sac I at the $5^{\prime}$ ends to facilitate subcloning. Sheared human genomic DNA $(5 \mu \mathrm{g})$ was amplified with $1 \mu \mathrm{M}$ primers in $10 \mathrm{mM}$ Tris $\cdot \mathrm{HCl}, \mathrm{pH} 8.3 / 50 \mathrm{mM} \mathrm{KCl} / 1.5$ $\mathrm{mM} \mathrm{MgCl} / 0.01 \%$ gelatin $/ 200 \mu \mathrm{M}$ each dATP, dCTP, dGTP, TTP $/ 10 \%$ dimethyl sulfoxide/ 2.5 units of Thermus aquaticus DNA polymerase (Taq DNA polymerase) (Perkin-Elmer/ Cetus) (16). The amplification profile was run for 25 cycles: $2 \mathrm{~min}$ at $92^{\circ} \mathrm{C}, 2 \mathrm{~min}$ at $45^{\circ} \mathrm{C}$, and $5 \mathrm{~min}$ at $72^{\circ} \mathrm{C}$.

Genomic Library Screening. A human placental genomic library in EMBL-3 SP6/T7 $\left(2.5 \times 10^{6}\right.$ recombinants; Clontech) was screened with the 900-base-pair (bp) PCR product labeled with ${ }^{32} \mathrm{P}$ by nick-translation. Duplicate nitrocellulose filters were hybridized in $6 \times \mathrm{SSC}(1 \times \mathrm{SSC}=0.15 \mathrm{M}$ sodium chloride/ $0.015 \mathrm{M}$ sodium citrate, $\mathrm{pH} 7.0) / 0.2 \%$ polyvinylpyrrolidone $/ 0.2 \%$ Ficoll $/ 0.2 \%$ bovine serum albumin $/ 0.1 \%$ sodium pyrophosphate $/ 0.1 \%$ SDS $/ 100 \mu \mathrm{g}$ of sheared salmon sperm DNA per ml at $42^{\circ} \mathrm{C}$ for $24 \mathrm{hr}$. Filters were then washed in $0.2 \times \mathrm{SSC}$ at $55^{\circ} \mathrm{C}$, and exposed at $-70^{\circ} \mathrm{C}$ with Kodak $\mathrm{X}$-OMAT film with Cronex enhancing screens.

Expression. To facilitate the construction of the expression vector, the initiator methionine codon of $\alpha_{2} \mathrm{C} 2$ was changed to an Nco I methionine codon. This was accomplished by synthesizing a 40-bp double-stranded oligonucleotide linker that matched the $\alpha_{2} \mathrm{C} 2$ sequence with $N c o$ I and $S f i$ I

Abbreviations: $\mathrm{G}$ protein, guanine nucleotide-binding protein; $\alpha_{2} \mathrm{AR}$, $\alpha_{2}$-adrenergic receptor; PCR, polymerase chain reaction.

${ }^{+}$The sequence reported in this paper has been deposited in the GenBank data base (accession no. M34041). 
restriction sites. This was ligated to the 1310-bp Sfi I/HindIII $\alpha_{2} \mathrm{C} 2$ restriction fragment and the $N$ co I/HindIII-cut mammalian expression vector $\mathrm{pBC} 12 \mathrm{BI} \beta_{2}(1)$. The resulting construct, $\mathrm{pBC} \alpha_{2}-\mathrm{C} 2$, contained $40 \mathrm{bp}$ of the $5^{\prime}$ untranslated region of the human $\beta_{2}$-adrenergic receptor adjacent to the Rous sarcoma virus promoter, followed by $1350 \mathrm{bp}$ of open reading frame, and 182 bases of $3^{\prime}$ untranslated region from the $\alpha_{2} \mathrm{C} 2$ clone. The construct was transfected into COS-7 cells by the DEAE-Dextran method (17).

Ligand Binding. COS-7 cells were harvested $48 \mathrm{hr}$ after transfection. Culture flasks $\left(75 \mathrm{~cm}^{2}\right)$ were rinsed with $5 \mathrm{ml}$ of TME solution ( $50 \mathrm{mM}$ Tris $\cdot \mathrm{HCl} / 10 \mathrm{mM} \mathrm{MgCl} / 2 \mathrm{mM}$ EDTA/ 1 $\mathrm{mM}$ phenylmethylsulfonyl fluoride, $\mathrm{pH}$ 7.4). Cells were then scraped and lysed in TME with a Brinkman homogenizer (model PT10/35, setting 5 for $5 \mathrm{sec}$ ). Membranes were washed once and stored at $-70^{\circ} \mathrm{C}$ until use. Approximately $50 \mathrm{fmol}$ of receptor per $0.25 \mathrm{ml}$ of assay mixture was incubated in TME at $25^{\circ} \mathrm{C}$ for $1 \mathrm{hr}$ with $\left[{ }^{3} \mathrm{H}\right]$ yohimbine $(79.1 \mathrm{Ci} / \mathrm{mmol} ; 1 \mathrm{Ci}=37$ $\mathrm{GBq})$. Assays were placed on ice, filtered onto Whatman GF/C membranes, and washed with ice-cold buffer. For competition curve analysis, each assay contained $5 \mathrm{nM}$ $\left[{ }^{3} \mathrm{H}\right]$ yohimbine. Nonspecific binding was determined for saturation curve analysis with $10 \mu \mathrm{M}$ phentolamine. Data were analyzed by computer with an iterative nonlinear regression program (18).

DNA Sequencing. Single-stranded DNA template was made from pTZ18R and pTZ19R (Pharmacia). Nucleotide sequence analysis of both strands was performed by the dideoxynucleotide chain-termination method $(19,20)$ by primer extension with T7 DNA polymerase (Sequenase; United States Biochemical).

Southern Blotting. Genomic DNA was extracted from fresh human kidney by standard techniques (21). DNA $(10 \mu \mathrm{g})$ was cut with $P$ st $I$ and run in a single lane on a $1 \%$ agarose gel. The gel was blotted onto nitrocellulose and hybridized in $50 \%$ formamide $/ 5 \times \mathrm{SSC} / 1 \times$ Denhardt's solution $/ 20 \mathrm{mM}$ sodium phosphate, pH 6.5/100 $\mu \mathrm{g}$ of sheared salmon sperm DNA per $\mathrm{ml} / 10 \%$ dextran sulfate $/ 2 \times 10^{6} \mathrm{cpm}$ of ${ }^{32} \mathrm{P}$-labeled probe per $\mathrm{ml}$ at $42^{\circ} \mathrm{C}$ for $12 \mathrm{hr}$. The blot was then washed in $0.2 \times$ SSC $/ 0.1 \%$ SDS at $55^{\circ} \mathrm{C}$ and exposed for 3 days.

Northern Blot Analysis. Total cellular RNA was isolated from fresh Sprague-Dawley rat tissues by the guanidinium isothiocyanate/cesium chloride method (22). Neonatal lungs were excised within $24 \mathrm{hr}$ after birth. Poly(A) ${ }^{+}$RNA was selected by using two cycles of oligo(dT)-cellulose chromatography. After denaturation by glyoxylation, the RNA was fractionated by agarose gel electrophoresis and transferred to membranes.

Pharmacological Agents. Sources of drugs were as follows: phentolamine (CIBA-Geigy); SKF 104078 (Smith Kline \& French); prazosin and UK 14304 (Pfizer Diagnostics); rauwolscine (Roth, Karlsruhe, F.R.G.); WB 4101 and paminoclonidine (Research Biochemicals, Natick, MA); corynanthine, oxymetazoline, epinephrine, and norepinephrine (Sigma); and [ ${ }^{3} \mathrm{H}$ ]yohimbine (New England Nuclear).

\section{RESULTS AND DISCUSSION}

The PCR was used to identify an $\alpha_{2}$ AR subtype. A similar method to isolate clones for several members of the $G$ protein and $G$ protein-coupled receptor families has recently been used $(23,24)$. First, regions of amino acid identity between the previously cloned human $\alpha_{2} \mathrm{ARs}, \mathrm{C} 4$ and $\mathrm{C} 10$, were identified. Then, oligonucleotides corresponding to the conserved nucleotide sequences were synthesized and used to amplify sheared human genomic DNA. A pair of such oligonucleotide primers (Fig. 1) representing the sense strand encoding the third transmembrane domain of $\alpha_{2} \mathrm{C} 4$ (nucleotides 402-431), and the antisense strand encoding the car- 


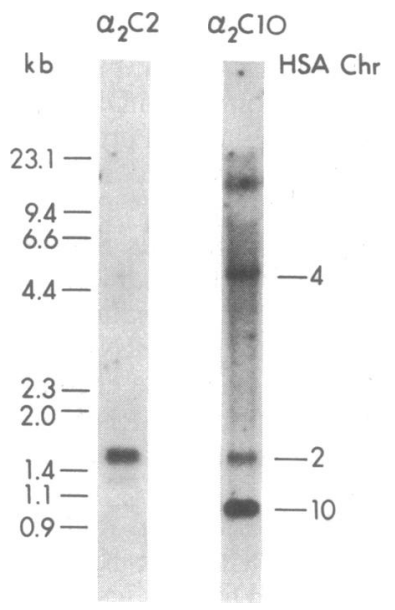

FIG. 2. Southern blot of Pst I-digested human genomic DNA, hybridized with the $\alpha_{2} \mathrm{C} 2$ PCR product and with a $0.95-\mathrm{kb}$ Pst I fragment of $\alpha_{2} \mathrm{C} 10$. The positions of the molecular size standards are indicated on the left. Chromosomal localizations are indicated on the right. The $0.95-\mathrm{kb}$ fragment corresponds to $\alpha_{2} \mathrm{C} 10$, the 5.9-kb fragment corresponds to $\alpha_{2} \mathrm{C} 4$, and the 1.6-kb fragment corresponds to $\alpha_{2} \mathrm{C} 2$. An additional unidentified fragment is seen at 1.3 $\mathrm{kb}$ with the $\alpha_{2} \mathrm{C} 2$ probe and at 16 $\mathrm{kb}$ with the $\alpha_{2} \mathrm{Cl0}$ probe.

boxyl end of the third cytoplasmic loop of $\alpha_{2} \mathrm{C} 4$ (nucleotides 1505-1526), was able to amplify a 900-bp fragment of DNA that was recognized by a probe made from the coding region of $\alpha_{2} \mathrm{C} 4$. In addition, the labeled PCR fragment hybridized to a 1.6-kilobase $(\mathrm{kb})$ fragment on a Southern blot of Pst I-digested human genomic DNA (Fig. 2). We have previously shown that a 1.6-kb Pst I fragment is identified with a probe from $\alpha_{2} \mathrm{C} 10$ and that this $1.6-\mathrm{kb}$ fragment localizes to human chromosome 2 (1). Hybridization of the PCR product with human somatic cell hybrids (25) showed that the gene is in fact located on chromosome 2 (data not shown).
The PCR fragment was subcloned into pTZ18R and sequenced. The deduced amino acid sequence contained regions of extensive homology to $\alpha_{2} \mathrm{C} 10$ and $\alpha_{2} \mathrm{C} 4$ (Fig. 3) in the putative second intracellular loop, fourth transmembrane domain $\left(\alpha_{2} \mathrm{C} 10,62 \% ; \alpha_{2} \mathrm{C} 4,38 \%\right)$, fifth transmembrane domain $\left(\alpha_{2} \mathrm{C} 10,73 \% ; \alpha_{2} \mathrm{C} 4,81 \%\right)$, and portions of the third cytoplasmic loop adjacent to the membrane. However, the majority of the putative third cytoplasmic loop was divergent from the previously cloned $\alpha_{2}$ ARs. Since there was extensive homology to the $\alpha_{2} \mathrm{ARs}$, yet also extensive divergence and a different chromosomal localization, the PCR fragment appeared to encode an $\alpha_{2} \mathrm{AR}$ subtype that we refer to here as $\alpha_{2} \mathrm{C2}$.

The $\alpha_{2} \mathrm{C} 2$ amplified DNA fragment was then used to probe a human genomic library to obtain a full-length clone. After screening at high stringency, a $15-\mathrm{kb}$ clone was isolated that contained a 1332-bp open reading frame uninterrupted by introns and 3000 bases of $5^{\prime}$ untranslated region. Fig. 1 shows the nucleotide and deduced amino acid sequence of the genomic clone. The open reading frame encodes a protein of 450 amino acids. Hydropathy analysis (26) of this amino acid sequence indicates that there are seven hydrophobic clusters of 20-25 residues, each separated by stretches of hydrophilic residues. This pattern is similar to that observed with the other members of the G-protein-coupled receptor family, in which the hydrophobic residues are thought to span the plasma membrane, and the hydrophilic stretches project from the membrane $(27,28)$. Thus, according to this topographic model, the amino terminus and three loops would extend into

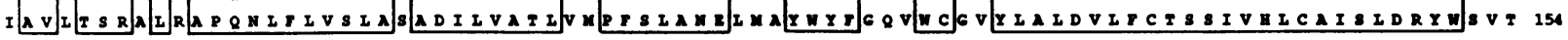

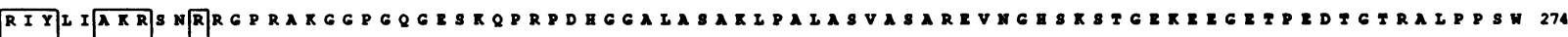

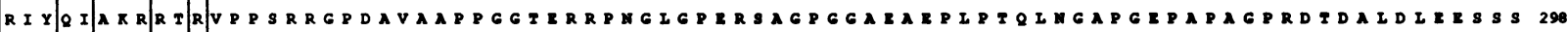

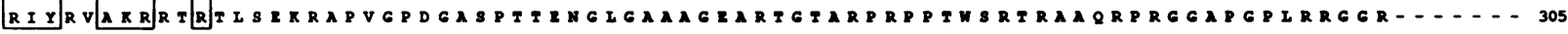

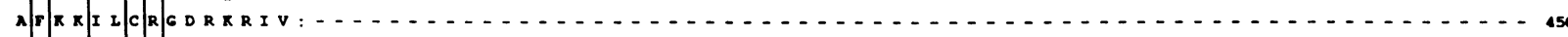

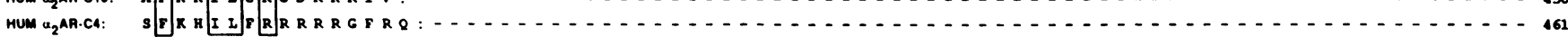

FIG. 3. Amino acid sequence alignment of the three human $\alpha_{2}$ ARs. Residues identical for all three receptors are boxed. 
the extracellular space, and the carboxyl terminus and three remaining loops would extend into the cytoplasm.

The putative transmembrane domains contain the highest concentrations of amino acids homologous to those in other G-protein-coupled receptors. Comparison of the deduced amino acid sequence of our clone with that of the other members of the G-protein-coupled receptor family shows that the highest homology is with the $\alpha_{2}$ ARs. Amino acid identities with $\alpha_{2} \mathrm{C} 2$ in the putative transmembrane domains of each human adrenergic receptor are as follows: $\alpha_{2} \mathrm{C} 4,75 \%$; $\alpha_{2} \mathrm{C} 10,74 \% ; \beta_{2}, 36 \% ; \beta_{1}, 39 \% ; \beta_{3}, 39 \% ; \alpha_{1 \mathrm{~B}}, 45 \%$ (D. A. Schwinn, personal communication). Fig. 3 shows the deduced amino acid alignment of the three human $\alpha_{2}$ ARs. The transmembrane domains are strikingly conserved, while the amino terminus, the carboxyl terminus, and the third cytoplasmic loop represent the most divergent domains.

The putative topography of $\alpha_{2} \mathrm{C} 2$ closely resembles that of $\alpha_{2} \mathrm{C} 10$ and $\alpha_{2} \mathrm{C} 4$ in that it has a long third intracellular loop and a short carboxyl terminus. Multiple serine and threonine residues present in these domains may be sites for phosphorylation by regulatory kinases such as $\beta$-adrenergic receptor kinase, which has been shown to phosphorylate the human platelet $\alpha_{2} \mathrm{C} 10$ (29). The carboxyl terminus contains a conserved cysteine (residue 432), which appears to be a site of palmitoylation in the family of G-protein-coupled receptors (30).

The amino terminus of $\alpha_{2} \mathrm{C} 2$ is among the shortest (12 amino acids) of the members of the G-protein-coupled receptors thus far cloned and lacks potential sites for $\mathrm{N}$-linked glycosylation. An $\alpha_{2}$ AR that appears not to be glycosylated has been described in neonatal rat lung (31). Fig. 4 shows that the $\alpha_{2} \mathrm{C} 2$ probe does not detect a mRNA species in rat neonatal lung, even though the rat neonatal tissue used contained $\approx 300 \mathrm{fmol}$ of $\alpha_{2} \mathrm{AR}$ binding per $\mathrm{mg}$ of protein (data not shown). Moreover, in this same tissue we were able to detect mRNA species for other adrenergic receptors $\left(\alpha_{1 \mathrm{~B}}\right)$ and actin (data not shown). Therefore, it appears that while $\alpha_{2} \mathrm{C} 2$ is without potential sites of $\mathrm{N}$-linked glycosylation in the amino terminus and extracellular loops, it is not equivalent to the rat neonatal lung receptor. The canine putative G-protein-coupled receptors RDC7 and RDC8, whose functions are unknown, also have similar short amino termini that lack glycosylation sites (24). The relationship between $\alpha_{2} \mathrm{C} 2$ and these receptors is at present unknown. Since $\alpha_{2} \mathrm{C} 2$ was cloned from a genomic library we cannot totally exclude the possibility that an intron exists somewhere in the amino terminus. However, the biochemical demonstration of a nonglycosylated $\alpha_{2} \mathrm{AR}$ (31) and the existence of two canine putative G-protein-coupled receptors with short amino termini lacking $\mathrm{N}$-linked glycosylation sites indicate that while the amino terminus of $\alpha_{2} \mathrm{C} 2$ is unusual, it is probably not unique.

To examine the ligand binding characteristics of $\alpha_{2} \mathrm{C} 2$, a construct containing the entire 1532-bp coding region and 182 bp of $5^{\prime}$ untranslated region was inserted into the mammalian expression vector $\mathrm{pBC} 12 \mathrm{BI}$ and was used to transiently transfect COS-7 cells. COS-7 cells transfected with the vector

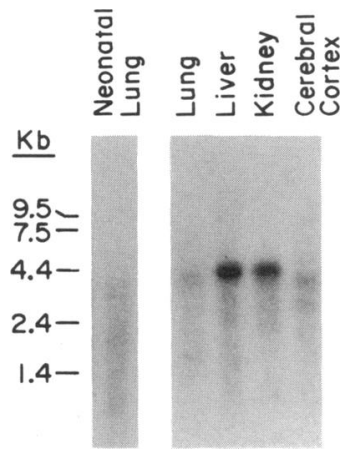

Fig. 4. Northern blot of rat tissues probed with the $\alpha_{2} \mathrm{C} 2 \mathrm{PCR}$ fragment. Each lane contains 10 $\mu \mathrm{g}$ of poly(A) ${ }^{+}$selected RNA. After hybridization, the filters were washed successively in $2 \times \mathrm{SSC} /$ $0.1 \%$ SDS at room temperature and $0.1 \times \mathrm{SSC} / 0.1 \%$ SDS at $55^{\circ} \mathrm{C}$, and exposed at $-70^{\circ} \mathrm{C}$ for 5 days. containing the $\alpha_{2} \mathrm{C} 2$ receptor sequence were able to bind the $\alpha_{2} \mathrm{AR}$ antagonist [ ${ }^{3} \mathrm{H}$ ]yohimbine in a saturable manner with high specific activity ( $2 \mathrm{pmol}$ per $\mathrm{mg}$ of protein) and affinity $\left(K_{\mathrm{d}}, 9.5 \mathrm{nM}\right)$. Nontransfected COS-7 cells exhibited no specific binding. Binding competition curves showed that the potency series for agonists [ $p$-aminoclonidine $>(-)$-norepinephrine $\geq(-)$-epinephrine $>(+)$-epinephrine] and antagonists (yohimbine $\geq$ rauwolscine $>$ prazosin $>$ corynanthine) exhibited $\alpha_{2}$ AR specificity and stereoselectivity. Table 1 shows the $K_{\mathrm{i}}$ values for various adrenergic compounds determined simultaneously for the three cloned human $\alpha_{2} \mathrm{ARs}$. It is apparent that the pharmacology of $\alpha_{2} \mathrm{C} 2$ is unique. Rauwolscine, corynanthine, WB 4101, and epinephrine appear to be useful in distinguishing $\alpha_{2} \mathrm{C} 2$ from $\alpha_{2} \mathrm{C} 4$, while prazosin and $p$-aminoclonidine distinguish $\alpha_{2} \mathrm{C} 2$ from $\alpha_{2} \mathrm{C} 10$. Oxymetazoline is the most useful drug as it discriminates between all three $\alpha_{2} \mathrm{ARs}$, having approximately a 10 -fold difference in affinity for each receptor.

The antagonist SKF 104078 appears to discriminate between the pre- and postsynaptic $\alpha_{2} \mathrm{ARs}$, as it has moderate affinity for the postsynaptic site (Kb, 70-150 nM), but low affinity for the presynaptic site $(\mathrm{Kb}, 3-30 \mu \mathrm{M})(32)$. The relatively high affinity for the compound SKF $104078\left(K_{\mathrm{i}}, 118\right.$ $\mathrm{nM}$ ) suggests that $\alpha_{2} \mathrm{C} 2$, like $\alpha_{2} \mathrm{C} 4$ and $\alpha_{2} \mathrm{C} 10$, is a postsynaptic receptor. This notion fits with the distribution of $\alpha_{2} \mathrm{C} 2$ as assessed by Northern blot analysis of various rat tissues shown in Fig. 4. mRNA for the receptor is clearly detected in adult rat liver and kidney.

The relatively high affinity for prazosin $\left(K_{\mathrm{i}}, 293 \mathrm{nM}\right)$ and low affinity for oxymetazoline $\left(K_{\mathrm{i}}, 1506 \mathrm{nM}\right)$ suggests that $\alpha_{2} \mathrm{C} 2$ is an $\alpha_{2} \mathrm{~B}$-like receptor. However, the absence of an $\alpha_{2} \mathrm{C} 2 \mathrm{mRNA}$ species in the cerebral cortex or neonatal lung, two model tissues for the $\alpha_{2} \mathrm{~B}$ receptor, suggests that this receptor is not the pharmacologically defined $\alpha_{2} B$. In fact we cannot clearly place $\alpha_{2} \mathrm{C} 2$ into any of the presently defined $\alpha_{2} \mathrm{AR}$ subtypes.

While the present pharmacological classification is useful, it is not sufficient. The isolation of distinct but related genes constitutes the most sensitive way to classify receptors. The expression of these single gene products in various cell systems will allow for detailed biochemical, molecular, and pharmacological analyses of the receptors and their coupled signal transduction pathways. These studies in conjunction with those of gene structure and receptor tissue distribution should lead to a more accurate and useful classification.

Recently, two preliminary reports have appeared describing the cloning of other $\alpha_{2}$ ARs $(33,34)$. Available information

Table 1. Competition by $\alpha$-adrenergic ligands for the binding of $\left[{ }^{3} \mathrm{H}\right]$ yohimbine to membranes from COS-7 cells transfected with either $\mathrm{pBC} \alpha_{2}-\mathrm{C} 2, \mathrm{pBC} \alpha_{2}-\mathrm{C} 4$, or $\mathrm{pBC} \alpha_{2}-\mathrm{C} 10$

\begin{tabular}{lccc}
\hline & \multicolumn{3}{c}{$K_{\mathrm{i}}, \mathrm{nM}$} \\
\cline { 2 - 4 } & $\mathrm{C} 2$ & $\mathrm{C} 4$ & $\mathrm{C} 10$ \\
\hline Agonists & & & \\
(-)-Epinephrine & 1851 & 318 & 1671 \\
(+)-Epinephrine & 8422 & $\mathrm{ND}$ & $\mathrm{ND}$ \\
(-)-Norepinephrine & 1265 & 606 & 3677 \\
Oxymetazoline & 1506 & 125 & 13.2 \\
p-Aminoclonidine & 120 & 97 & 31 \\
Antagonists & & & \\
Corynanthine & 1002 & 182 & 1188 \\
Phentolamine & 9.2 & 14.4 & 6.2 \\
Prazosin & 293 & 67.7 & 2237 \\
Rauwolscine & 11 & 2.1 & 7.1 \\
SKF 104078 & 105 & 41 & 97 \\
WB 4101 & 132 & 13 & 47 \\
\hline
\end{tabular}

The results shown are representative of two experiments, each done simultaneously for all three receptors. The expression vectors $\mathrm{pBC} \alpha_{2}-\mathrm{C} 4$ and $\mathrm{pBC} \alpha_{2}-\mathrm{C} 10$ were constructed as described (2). ND, not determined. 
about these clones suggests that they are different from $\alpha_{2} \mathrm{C} 10, \alpha_{2} \mathrm{C} 4$, and $\alpha_{2} \mathrm{C} 2$.

We are grateful to Sabrina Exum, Kiefer Daniel, and Pam Szklut for technical assistance and to Mary Holben for manuscript preparation. We also thank Dr. Mark R. Hnatowich and Dr. Susanna Cotecchia for helpful discussions. J.W.L. is supported by the Stanley J. Sarnoff Endowment for Cardiovascular Science, and W.L. is supported by the Deutsche Forschungsgemeinschaft. This work was also supported in part by Grant HL16037 from the National Institutes of Health.

1. Kobilka, B. K., Matsui, H., Kobilka, T. S., Yang-Feng, T. L., Franke, U., Caron, M. G., Lefkowitz, R. J. \& Regan, J. W. (1987) Science 238, 650-656.

2. Regan, J. W., Kobilka, T. S., Yang-Feng, T. L., Caron, M. G., Lefkowitz, R. J. \& Kobilka, B. K. (1988) Proc. Natl. Acad. Sci. USA 85, 6301-6305.

3. Frielle, T., Collins, S., Daniel, K. W., Caron, M. G., Lefkowitz, R. J. \& Kobilka, B. K. (1987) Proc. Natl. Acad. Sci. USA 84, 7920-7924.

4. Kobilka, B. K., Dixon, R. A. F., Frielle, T., Dohlman, H. G., Bolanowski, M. A., Sigal, I. S., Yang-Feng, T. L., Franke, U., Caron, M. G. \& Lefkowitz, R. J. (1987) Proc. Natl. Acad. Sci USA 84, 46-50.

5. Schwinn, D. A., Lomasney, J. W., Lorenz, W., Szklut, P. J., Fremeau, R. T., Yang-Feng, T. L., Caron, M. G., Lefkowitz, R. J. \& Cotecchia, S. (1990) J. Biol. Chem., in press.

6. Cotecchia, S., Schwinn, D. A., Randall, R. R., Lefkowitz, R. J., Caron, M. G. \& Kobilka, B. K. (1988) Proc. Natl. Acad. Sci. USA 85, 7159-7163.

7. Emorine, L. J., Marullo, S., Brieno-Sutren, M.-M., Patey, G. Tate, K., Delavier-Klutchko, C. \& Strosberg, A. D. (1989) Science 245, 1118-1121.

8. Dohlman, H. G., Caron, M. G. \& Lefkowitz, R. J. (1987) Biochemistry 26, 2657-2664.

9. Bylund, D. B., Ray-Prenger, C. \& Murphy, T. J. (1988) J. Pharmacol. Exp. Ther. 245, 600-607.

10. Bylund, D. B. (1985) Pharmacol. Biochem. Behav. 22, 835843.

11. Murphy, T. J. \& Bylund, D. B. (1987) J. Pharmacol. Exp. Ther. 244, 571-578.

12. Bylund, D. B. (1988) Trends Pharmacol. Sci. 9, 356-361.
13. Drew, G. M. \& Whiting, S. B. (1979) Br. J. Pharmacol. 67, 207-215.

14. Langer, S. A. (1974) Biochem. Pharmacol. 23, 1793-1800.

15. Becker, B. R., Efcavitch, W. J., Heiner, C. R. \& Kaiser, N. F. (1985) J. Chromatogr. 326, 293-299.

16. Saiki, R. K., Gelfland, D. H., Stoffel, S., Scharf, S. J., Higuchi, R., Horn, G. T., Mullis, K. B. \& Erlich, H. A. (1988) Science 239, 487-491.

17. Cullen, B. R. (1987) Methods Enzymol. 152, 684-704.

18. Delean, A., Hancock, A. A. \& Lefkowitz, R. J. (1982) Mol. Pharmacol. 21, 5-16.

19. Vieira, J. \& Messing, J. (1982) Gene 19, 259-268.

20. Sanger, F., Nicklen, S. \& Coulson, A. R. (1977) Proc. Natl. Acad. Sci. USA 74, 5463-5467.

21. Maniatis, T., Fritsch, E. F. \& Sambrook, J. (1982) Molecular Cloning: A Laboratory Manual (Cold Spring Harbor Lab., Cold Spring Harbor, NY).

22. Chirgwin, J. M., Przybyla, A. E., MacDonald, R. J. \& Rutter, W. J. (1979) Biochemistry 24, 5294-5299.

23. Strathmann, M., Wilkie, T. M. \& Simon, M. I. (1989) Proc. Natl. Acad. Sci. USA 86, 7407-7409.

24. Libert, F., Parmentier, M., Lefort, A., Dinsart, C., Van Sande, J., Maenhaut, C., Simons, M.-J., Dumont, J. E. \& Vassart, G. (1989) Science 244, 569-572.

25. Yang-Feng, T. L., Landau, N. R., Baltimore, D. \& Franke, U. (1986) Cytogenet. Cell Genet. 43, 121-126.

26. Kyte J. \& Doolittle, R. F. (1982) J. Mol. Biol. 157, 105-132.

27. Dohlman, H. G., Bouvier, M., Benovic, J. L., Caron, M. G. \& Lefkowitz, R. J. (1987) J. Biol. Chem. 262, 14282-14288.

28. Wang, H.-Y., Lipfert, L., Malbon, C. C. \& Bahouth, S. (1989) J. Biol. Chem. 264, 14424-14430.

29. Benovic, J. L., Regan, J. W., Matsui, H., Mayor, F., Cotecchia, S., Leeb-Lundberg, L. M. F., Caron, M. G. \& Lefkowitz, R. J. (1987) J. Biol. Chem. 262, 17251-17253.

30. O'Dowd, B. F., Hnatowitch, M., Caron, M. G., Lefkowitz, R. J. \& Bouvier, M. (1988) J. Biol. Chem. 264, 7564-7569.

31. Lanier, S. M., Homcy, C. J., Patenande, C. \& Graham, R. M. (1988) J. Biol. Chem. 263, 14491-14496.

32. Hieble, J. P., Sulpizio, A. C., Nichols, A. J., Demarinis R. M., Pfeiffer, F. R., Lavanchy, P. G. \& Ruffulo, R. R. (1986) J. Hypertens. 4, Suppl. 6, 5189-5192.

33. Weinchank, R. L., Lichtblau, H. M. \& Hartig, P. R. (1989) Soc. Neurosci. Abstr. 15, 73.3 .

34. Harrison, J. K., Zeng, D., D’Angelo, D. D., Tucker, A. L., Lu, Z., Barber, C. M. \& Lynch, K. R. (1990) FASEB J. 4, 3141 (abstr.). 